\title{
Dominant Carrier Performance and International Liberalization \\ - the case of Northeast Asia
}

\author{
Xiaowen $\mathbf{F u}^{*}$ \\ Institute of Transport and Logistics Studies, University of Sydney, Australia \\ *Corresponding Author: Email: xiaowen.fu@sydney.edu.au \\ Tae Hoon Oum \\ Sauder School of Business, University of British Columbia, Canada \\ Email: tae.oum@sauder.ubc.ca \\ Ruowei Chen \\ Shanghai Aircraft Design and Research Institute, COMAC, China \\ Email: chenruowei@ comac.cc

\section{Zheng Lei} \\ Centre for Aviation Research, University of Surrey, UK \\ E-mail: zheng.lei@ surrey.ac.uk
}

\begin{abstract}
This study investigates the links between domestic market regulation, dominant airline performance, and international market liberalization in Northeast Asia (NEA). The study focuses on China, where substantial regulations are still present in the aviation market, particularly in areas such as route entry, airport slot allocation, input supply, and aviation support services. These regulations limit the ability of entrant airlines to compete in hub airports, and allow dominant airlines to strengthen their market power and achieve substantial growth at the expense of their competitors. Current Chinese regulations assist major stateowned carriers by suppressing domestic competition, particularly in markets linked to hub airports. If national policy in China continues to be guided by requirements created to support the dominant airlines, in the short term there will be limited liberalization on routes linked with hub airports. Promoting LCC services in the region is one practical alternative for the short term which could prevent major disruption to network carriers. This investigation suggests that Chinese airlines would be less resistant to bilateral liberalization with ASEAN, Oceanian or European nations than they would with other regions, as they are well positioned in these markets, and may be able to develop their hub airports into Asia's gateways to Europe. In the long term, however, there is no substitute for full liberalization if NEA governments want their nations to fully benefit from enabling their carriers and hub airports to achieve global competitiveness.
\end{abstract}

Keyword: air transport liberalization, dominant airlines, North East Asia, airline competition

Acknowledgement: This paper is based on research funded by the ITF/OECD. It was presented at a special session on aviation liberalization, co-organised by the ITF/OECD and the 18th ATRS World Conference, held in Bordeaux, France, on July 17-20, 2014. The authors gratefully acknowledge the excellent comments and suggestions from Dr. Paul Hooper (the guest editor), two anonymous referees, Dr. Antigoni Lykotrafit and participants of the OECDITF Workshop of Aviation Liberalization. All remaining errors are ours. 


\section{Introduction}

Numerous studies of the aviation industry have confirmed that significant benefits can result from liberalizing the international market. Fu and Oum (2014), after a comprehensive review of the literature, concluded that there is strong evidence that liberalization brings substantial economic benefits to the countries involved. Liberalization has led to increased airline competition, lower average fares, increased frequency, improved load factor and airline productivity, increased traffic volumes, and new route services. These changes have not only resulted in higher employment and economic output in the aviation industry, but have also led to improvements in related sectors such as tourism, trade, and logistics. Despite these obvious benefits, many governments have been cautious towards embracing full liberalization. In 2003, 57 liberalization agreements out of a total of 87 involved the U.S. As of October 2012, over 400 liberalized agreements were reached among 145 economies, of which more than 100 were U.S. open-skies agreements (ICAO 2013). Hooper (2014) noted that liberalization has gained a certain degree of momentum, but many countries are yet to eliminate restrictive regulations due to the concern about fair competition, and the fear that foreign airlines may dominate liberalized markets.

Though slow, limited progress in aviation liberalization has been achieved in the Northeast Asian (NEA) region. These achievements have led to substantial growth in air traffic and service frequency for liberalized markets. In 2006, an open skies agreement was signed between Korea and the Chinese province of Shandong. In 2007, Korea and Japan signed their bilateral open-skies agreement, with the exclusion of Japanese metropolitan markets involving Tokyo's Narita and Haneda airports, which have capacity constraints. An agreement to liberalize services between Tokyo's Narita International Airport and Incheon International Airport was subsequently reached in 2010, thanks to the airport capacity expansion projects in the Tokyo area. Considering the potential of this region, which comprises the world's second, third, and fifteenth largest economies (i.e. China, Japan, and Korea ${ }^{1}$ ), with a combined population totaling over 1.5 billion, the NEA international aviation market could have grown much faster had there been more liberalized bilateral air service agreements (ASAs). Therefore, it is valuable to investigate why governments in this region have not achieved more, and whether a clear roadmap can be designed to accelerate the process of liberalization in the coming years.

Despite an increasing body of literature on air transport liberalization in recent years, there has been little examination of performance changes resulting from the liberalization process with dominant airlines, nor has there been an examination of the ways in which the competitiveness of a country's aviation sector influences government policy on international transport. Dominant airlines often exert significant influences throughout the liberalization process. In fact, many governments have a history of supporting their "flag carriers". For example, many European flag carriers involve state ownership, and governments have repeatedly helped their failing carriers (e.g. Sabena, Air France, Iberia, Alitalia). However, over time a number of airlines have been privatized, and under the EU requirement of "market economy investor principle" EU country governments are no longer allowed to provide state aid to their airlines ${ }^{2}$. This is not the case in the NEA region. In China, other than a few niche players such as Spring and Juneyao, most airlines are majority-owned by either the central or local government. The Chinese government now recognizes the "decisive role" played by markets in allocating resources ${ }^{3}$, but there is still no clear separation between its role as airline

\footnotetext{
${ }^{1}$ At 2012 current price in US dollars, based on estimates by the United Nations Statistics Division.

${ }^{2}$ These principles however were not strictly followed in EU. For detailed discussions see Lykotrafiti (2008).

${ }^{3}$ Decision made at the third plenary session of the 18th Communist Party of China Central Committee, held in Nov 2013.
} 
owner and airline regulator. The influence of dominant airlines in China on aviation policies will not fade away quickly.

Investigating the performance of major airlines, both overall and within the domestic market, helps predict their performance in the international market, and therefore informs the development of international strategies. Thus the attitude of regulators toward alternative liberalization policies can be examined. Many studies have examined the relationship between domestic market structures and export services. There are broadly two streams of literature here: the national-champion theory argues that with suppressed competition in domestic markets, firms can achieve large scale operations which enable them to obtain large market shares and profits in export markets (see Pagoulatos and Sorensen, 1976; Marvel, 1980; Krugman, 1984; Chou, 1986, for example). The second literature stream supports the competition theory, in which stiff competition in the domestic market forces firms to improve and innovate, thus achieving global competitiveness in the export market (see Audretsch and Yamawaki 1988; Porter 1990; Clark et al. 1992; Kim and Marion, 1997; Sakakibara and Porter, 2001, for example). Clougherty and Zhang (2009) examined the airline market, and found that if an airline can improve its domestic performance, it is more likely to successfully compete in overseas markets.

This study aims to investigate the links between domestic market regulation/deregulation, airline performance, and the liberalization of international markets in the NEA region, with a focus on China. As the world's second largest aviation market after the US, the effects of China's liberalization policies on the NEA region, and globally, are significant. Japan and Korea have made major progress in opening their skies to each other and to a few other countries. In comparison, the Chinese government has been more conservative after some initial opening up in 2007, when the bilateral service agreement between China and the US allowed the operation of more flights and designated airlines. Airlines in Korea and Japan have been privatized for some time, but the principle carriers in China are still majority-owned by the state. These close government ties may allow Chinese carriers to exert great influence over national policy. Despite the implementation of certain deregulation policies, there are still legacy regulations in the Chinese domestic market which limit competition. If these internal regulations for the domestic market cannot be phased out, it is unlikely they will be removed from the international market any time soon. An examination of the status of the Chinese domestic market, in particular the performance of major airlines, will contribute to a better understanding of Chinese regulator's aims and priorities. It will also help predict the future policy decisions of regulators. For the reasons mentioned here, this study will focus on the aviation market in China, while those of Korea and Japan will be discussed only if it is necessary to benchmark across the three countries.

The remainder of this paper is organized as follows. Section 2 reviews the development path and current status of aviation markets in the NEA region, including domestic deregulation, international liberalization and the performance of major airlines. Section 3 discusses possible concerns of the Chinese government if a "national champion" philosophy is adopted to help major carriers to achieve large scale and global competitiveness. Section 4 reviews the development status of LCCs in the region, and whether they can promote liberalization in the NEA region without generating substantial market disruptions. The last section summarizes and concludes the study.

\section{Domestic market development and status of major airlines}

Over the past few years the Chinese aviation sector has experienced tremendous growth as the economy rapidly expanded and major investments were made in transport infrastructure 
such as airports and air traffic control systems. The number of air passengers grew at an annual rate of $14.9 \%$ between 1990 and 2010. However, measuring the performance and competitiveness of Chinese airlines is not straightforward. In 2010, the earnings of Chinese carriers reached RMB35.1 billion (USD5.18 billion), about $60 \%$ of the industry's global profits that year. However, China Eastern Airlines, the second largest carrier in the country, received a government capital injection of RMB10 billion (US $\$ 1.45 \mathrm{bn}$ ) in 2009, and over RMB3 billion (US $\$ 0.44 b n$ ) in 2012, to reduce its exceedingly high debt ratio. The other two largest airlines, China Southern and Air China, also received capital injections in 2012, of RMB2 billion (US\$0.29bn) and RMB1 billion (US\$0.15bn), respectively. There was no economic recession during this time, nor any major disruptive event such as the SARS outbreak or terrorist attacks. Therefore, though Chinese airlines appear to have grown rapidly in terms of scale, their performance needs to be carefully examined. This section reviews market structure and development paths in performance of the Chinese aviation market. Strategies of Chinese carriers towards liberalization and deregulation can be interpreted and evaluated based on reviews of market performance.

\subsection{The development path of Chinese domestic market}

Before 1978, the Chinese aviation industry was operated as a quasi-military unit. Commercialization of airlines began in March 1978, when the management/regulatory authority was transferred from the air force to the State Council. It was not until 1987 that airlines were corporatized. At that time six major state-owned airlines, Air China, China Southern, China Eastern, China Southwest, China Northwest, and China Northern, were formed based on six regional bureaus. Starting in 2002, significant restructuring policies were introduced in the aviation sector: market consolidation, government control, and new roles for provincial and municipal governments.

- Market Consolidation: From 2002 the Chinese government initiated market consolidation among major carriers: China Eastern Airlines merged with China Northwest and Yunnan airlines, China Southern took over China Northern and Xinjiang airlines, and Air China gained control of China Southwest and CNAC airlines. In 2010 the market was further consolidated when China Eastern acquired Shanghai Airlines and Air China controlled Shenzhen Airlines. Consolidated airlines also established many subsidiary carriers, often jointly with local governments serving as niche operators in regional markets. For example, Air China holds shares in Shandong Airlines, Tibet Airlines, Dalian Airlines, Air China Inner Mongolia, and Air Macau. The same consolidation strategy has been adopted by other major airlines such as China Southern, China Eastern, and Hainan Airlines. In summary, the Chinese government has allowed, and in many cases coordinated, mergers and consolidation in the airline market. Competition or anti-trust issues have not been a serious concern to the regulator.

- Government control: The preference for scale and government control is also evident in the input supply market. The China National Aviation Fuel (CNAF), a Fortune 500 company, holds the de facto monopoly of aviation fuel in China, though some airlines have limited control of fuel supplies in a few domestic airports. The China Aviation Supplies Holding Company, another state-owned company, has a significant market share in aircraft purchase and leasing. The China Travel Sky Holding Company provides the IT backbone for domestic ticket sales and reservations, and airport passenger systems for over 100 airports. In 2002, the six aviation groups (i.e. Air China, 
China Eastern and China Southern airline groups, CNAF, China Aviation Supply, and China Travel Sky) were "detached" from the Civil Aviation Administration of China (CAAC) and are now under the control of the State-owned Assets Supervision and Administration Commission of the State Council. Ties between CAAC and these statecontrolled groups still remain strong. Many senior officials at CAAC serve as top executives of these six groups.

- Roles of provincial and municipal governments: Provincial and municipal governments play significant roles in the aviation industry. Apart from Beijing Capital Airport and the airports in Tibet, all other airports had been transferred to local governments by 2004. Although airport operations and pricing are regulated by the central government, local governments are responsible for airport investments. Airports are classified into different "categories," each under a set of pricing schemes defined by the CAAC. In addition, many second-tier airlines (in terms of size) are founded/co-founded by local governments, mainly to promote aviation services to their specific province or city. Therefore, interests and objectives of local governments are usually consistent with their own airports, but not always consistent with those of the airlines. Airlines are most concerned about their own revenues and profits, while local governments are most concerned with traffic volume and service quality in their regions, as better aviation services contribute to the well-being of local airports and economies.

Compared to the aviation markets in developed economies, the commercialization process of Chinese markets started much later. Currently, all major carriers are majority-owned and managed by either central or local governments. Most input and supporting services are also controlled by state-owned companies holding significant market power. The central government owns the largest three airline groups and the dominant/monopoly companies which provide fuelling services, ticketing and airport IT services, and fleet purchasing services. The regulator has shown little concern over market consolidation or the reduction of competition. Only a few private airlines have been allowed to enter the market, and they are much smaller than their state-owned counterparts. Most airports are under the control of local governments, which are responsible for financial performance and infrastructure investments. Therefore, these local governments may have different objectives from those of the dominant carriers. Local governments are generally concerned with better aviation services in their respective regions, which benefit local airports and social welfare.

\subsection{Airline route entry, network development, and airline competition}

Route and network planning is very important as this directly affects airlines' costs and revenue. Piermartini and Rousova (2008) reviewed Air Service Agreements (ASAs) in international markets, and found that although $60 \%$ of the ASAs allow multiple designations, $40 \%$ permit single designation only. Thus, two airlines at most compete for the specific international routes. Fu et al. (2010) and Fu and Oum (2014) concluded that liberalization allows airlines to optimize their networks for various objectives: to improve cost efficiency by exploiting "economies of traffic density", to enhance service quality by initiating direct flights and/or by increasing flight frequency, to price more aggressively, or to compete more strategically. Regulation on route entry has been removed in most mature markets in North America and Europe, and in Asia-Pacific countries such as Japan, Korea, Australia, and New Zealand.

In the Chinese domestic markets, route entry and airport slot allocations are monitored and/or regulated depending on whether hub airports are involved. The details of the regulations 
have evolved over the years. Currently, when airlines plan to enter a new market defined as an airport-pair, they need to either apply for approval or simply register/report in advance. The following three types of route entry must be approved: (I) when the entry involves an airport that is slot controlled or capacity constrained as defined by the regulator, (II) when the entry involves busy airports or routes with large traffic volume, or (III) airports that have special arrangements related to the safety of flight operations. However, for the following three types of route entry an airline only needs to register/report in advance but does not need to seek approval: (1) airport pairs not included in I-III above, (2) cargo flights, or (3) airport pairs defined by the CAAC or regional bureaus.

Before 2010, approvals for route entry were required for most large airports in provincial capital cities and metropolitan areas. Under the current rules, entries involving the four airports in Beijing, Shanghai, and Guangzhou (i.e. Beijing Capital Airport, Shanghai Hongqiao Airport, Shanghai Pudong Airport, and Guangzhou Baiyun Airport) need to be approved. However, airlines that use these four airports as hubs do not need to seek approval for flights from them to other destinations. For example, Air China has a hub at Beijing, so there is no need to seek approval for flight between Beijing and Xi'an, but the carrier needs to apply to increase frequency between Beijing and Shanghai. As of December 2013, 88\% of the entry rights to 3,353 domestic routes were by registration only without the need to seek formal approval. This ratio has been increasing over the years.

In addition to route entry regulation, there are also slot controls in congested airports. Airport slot allocation and coordination are under the control of the central government (i.e. the CAAC) and regional bureaus. Regional bureaus are responsible for domestic airline flights and the CAAC coordinates slots for international flights. Traffic volumes have outpaced airport capacity growth in many destinations, so in recent years an increasing number of airports have required slot coordination, as reported in Table 1:

\section{$<$ Table 1 here >}

When a regional bureau manages airport slots, an allocation committee is formed, which comprises representatives from the regional bureau, regional air traffic control, airlines, and the airport. One key responsibility of this committee is to suggest the slot allocation ratio between hub carriers vs. airlines based in other airports. Committee members vote on important decisions, with an overall allocation of 1,000 votes for each topic requiring a vote. Based on the shares of allocated slots in the previous year, a total of 600 votes are distributed among the airlines, and the remainder of the voting rights are shared among regional bureaus, airports, and air traffic control agencies. For routine operation and management, airport slots are allocated among the following services, in order of priority:

1. Existing flights (i.e. grandfathered rights)

2. Entrant airlines initiating services at the airport

3. Hub carriers with priority over non-hub carriers

4. New routes by airlines currently serving the airport

5. Airlines achieving high utilization rates of current slots

In view of the current practices in the global aviation industry, the slot allocation regulations in China are not unreasonable. In mature markets, such as Europe and North America, the first step of slot allocation is to prioritize incumbent airlines with existing slots so they can obtain and maintain the same slots in the next period ("grandfather rights"). If the existing slots are to be protected for the next period, they must be used at least $80 \%$ of the time in the current period (the "use it or lose it" rule). Once the grandfather rights are confirmed, 
the remaining slots, together with those newly created (through improved air control technology, voluntary relinquishment, insufficient use, or added capacity) are grouped in a 'slot pool', and up to $50 \%$ are set aside for new entrants (the "new entrant" rule). The rest are allocated free of charge to incumbents. This slot allocation approach, characterized by "grandfather rights," the "use it or lose it" rule, and the "new entrant" rule is currently adopted in many countries, but it has long been criticized as inefficient (Matthews and Menaz, 2003). For example, an incumbent airline may deter entrant airlines by scheduling small-sized aircraft over non-core routes, or by leasing slots to alliance members for a short period, so the incumbent can continue to hold onto slots that are under-utilized. With "slot baby-sitting" strategies such as these, incumbent airlines may deter entrants by preempting the markets via airport slot hoarding. Many studies, including those commissioned by governments, have investigated the use of slot auctions or other market-based instruments (e.g., congestion pricing, slot sales, and slot trading) thus slots are allocated to carriers that attach the highest economic value to them (DotEcon, 2001 and 2006; Sentance, 2003; Maldoom, 2003; National Economic Research Associates, 2004; Madas and Zografos, 2006, 2008 and 2010; Brueckner, 2009; Verhoef, 2010). However, these proposals have largely remained theoretical, as they face various practical challenges and political concerns.

In China, the regulations for both route entry and airport slot allocation are much more restrictive than those adopted in mature markets such as Europe and North America (e.g. London Heathrow, JFK, Chicago O'Hare, etc.). In these mature markets, once a slot is secured and in use, the airline can use it for any route without seeking further approval. Chinese airlines, however, often need to secure approval for both route entry and airport slots when they enter or add frequencies in routes linking to hubs in metropolitan areas (i.e. Beijing, Shanghai, and Guangzhou). In the European and North American mature markets it has been a common practice to give priorities to new entrant airlines or new services, while in the Chinese domestic market, the hub carriers receive preferential treatment. With the exception of the four regulated airports in China, there is no need for hub carriers to seek route entry approval for initiating services to their own hub airports. These carriers also have priority in securing airport slots at their hubs. It has been claimed by the regulator that these policies have two objectives: to promote competition and to facilitate dominant airlines developing their hubs. However, the preferential treatment given to hub carriers makes it difficult for other airlines to compete at major hubs. This is in marked contrast to the policies adopted by the US Department of Transportation, which has attempted to introduce competition at hub airports and to control the market power of hub carriers. ${ }^{4}$

\subsection{Performance of aviation markets and major airlines}

There is a two-way relationship between government policy and market performance in China. On the one hand, aviation policies have been revised over the years to reflect changing market conditions and to achieve evolving policy objectives. On the other hand, these policies have significantly influenced the market equilibrium and therefore the performance of airlines. For example, large airports in China account for a significant proportion of the national market,

\footnotetext{
${ }^{4}$ Many studies on the US aviation markets have found that dominance at an airport allows a carrier to achieve substantially higher mark-up above cost, a benefit known as the "hub premium" in the literature (Borenstein, 1989; GAO, 1989 and 1990). The U.S. Department of Transportation (DOT, 2001) believes that it was the lack of price competition, not those other rationales, that explained high prices at hub markets. Therefore, it is required that each of the large airports with a "dominant" carrier must submit a plan on how they intend to promote airport access, entry and competition to the US Department of Transportation (DOT) (FAA, 1999). The requirement of submitting a competition plan was incorporated into the "Wendell H. Ford Aviation Investment and Reform Act for the 21 st Century" legislated in 2000 . According to this act, large and medium airports that exceed a certain threshold of concentration are required to submit competition plans.
} 
therefore special arrangements regarding route entry and slot allocation have been made at these airports. Government policies have given preferential consideration to hub carriers, who have been able to further strengthen their market positions at major hubs and in the national market. The market shares of the top ten airports for the 1998-2009 period are reported in Table 2. Over the years, they have accounted for more than half of the national passenger market and more than $70 \%$ of the national cargo markets. It is therefore of critical importance for airlines to secure their market shares at major airports.

\section{$<$ Table 2 here >}

The overall effects of route entry and slot allocation are unclear. As shown in Table 3, flight frequency has substantially increased, though with significant variations among airports of different sizes. However, the average aircraft size for flights linking the largest airports actually decreased from 2002 to 2008. This could reflect the progress of Chinese carriers in constructing hub-and-spoke networks (which require extensive feeder operations using small aircraft), or the increasing quality of airline services with reduced schedule delays. On the other hand, it may be an indication that precious airport slots could have been better utilized with larger aircraft, or that the current slot allocation scheme is not optimal from the perspective of social welfare. Zhang et al. (2013, 2014) examined airline competition in China and found a hub-premium effect similar to the result identified in the US airline market. Wang et al. (2014a) also noted that the yields of Chinese carriers on the largest routes are slightly higher than the average yield in the United States. Considering the lower per capita income and input prices in China, airline competition is certainly not at the level it should be.

\section{$<$ Table 3 here>}

The dominant airlines in China have been able to take advantage of many favorable factors over the past decades: the Chinese economy has been growing rapidly, leading to very high demands for air travel. Such demand growth has been particularly high in major airports, where hub carriers enjoy substantial competitive advantages under the regulations of route entry and airport slot allocation. The Chinese government has encouraged major airlines to further consolidate, and the leading carriers were therefore able to scale up remarkably quickly. Table 4 shows that Chinese airlines have been growing much faster than their peers in the NEA region. In 2001, levels of revenue, passengers carried, and numbers of aircraft for Chinese carriers were barely comparable to their Japanese and Korean competitors. However, during the period 2001 to 2012, the "big three" Chinese carriers (Air China, China Southern, and China Eastern) recorded about $700 \%$ growth in revenue. In comparison, Korean carriers increased revenue by less than 300\%, and Japanese carriers by less than 50\%. By 2012, in terms of revenue, passengers and aircraft, Chinese carriers had grown to almost twice the size of the nearest competitor from either country. It is clear that Chinese airlines have achieved remarkable growth in scale. Hooper et al. (1996) and Hooper (1998) compared the (on-going) deregulation process in India to those in developed countries. Their studies concluded that although the level of economic development is an important determinant of market performances, the fundamental economics of the airline industry apply to both developing and developed countries. The Indian market has sufficient scale to support competition, which provides the most powerful incentives for efficiency and responsiveness to consumers' demands. Although China will remain as a developing country in the foreseeable future, its major carriers are now among the largest airlines in the world. Policies designed to protect them make little sense. 
Chinese airlines were also able to grow their profits significantly, albeit slightly slower than the growth in scale. Table 4 shows that the profits of the Chinese "big three" grew by over $500 \%$ from 2001 to 2012 . However, they barely improved their competitiveness in the global market, as the "national champion" theory predicted - the share of international traffic in terms of revenue passenger kilometers (PRK) actually decreased between 2001 and 2012, and lagged far behind other major network carriers in NEA. Domestic success has not enabled Chinese airlines to bridge the gap of competitiveness with other airlines. Wang et al. (2014a) benchmarked the Total Factor Productivity of Chinese airlines against major network carriers in Europe, Asia, and North America. They concluded that although Chinese airlines were able to significantly improve their efficiency, the efficiency gaps with North American carriers actually grew, as reported in Table 5.

\section{$<$ Table 5 here $>$}

In summary, major airports are of critical importance to Chinese airlines due to their large market potential. However, traffic growth has outpaced capacity in these markets, making government regulation on route entry and slot allocation a critical factor in determining the performance of airlines. Route entry regulation has been phased out in all but four major airports in the metropolitan areas, but an increasing number of airports are under slot control. The route entry and airport slot allocation mechanisms together favor hub carriers' network development, while putting other airlines at a significant disadvantage. Flight frequencies have increased rapidly in all airports, resulting in a better quality of service and reduced schedule delay for travelers. However, the average aircraft size has actually decreased slightly for the ten largest airports. This may reflect the efforts of airlines to build up hub-and-spoke networks, but may also suggest that precious slots are not optimally utilized. Chinese airlines have been able to achieve very high yield in dense routes, due to a lack of competition in the domestic markets, particularly in routes linking hub airports.

The phenomenal growth in the domestic markets enabled Chinese carriers to expand and increase their profits. However, success in domestic markets did not make them substantially more competitive in international markets. Efficiency levels are still far behind those of industry leaders, and Chinese airlines' shares of international revenue have decreased over the past decades, remaining well below their NEA counterparts. In summary, Chinese airlines are now well positioned to compete globally in terms of scale, but they have yet to identify a strategy for fully leveraging the favorable conditions they have enjoyed domestically. The following section examines their global competitiveness, and their preferences for international aviation policy.

\section{Implications of liberalization for dominant airlines}

Many studies have examined the effects of liberalization using observed industry data. These ex post studies found strong evidence that if the well-being and social welfare of travelers are considered alongside airline profits, liberalization generally brings significant benefits to all countries involved. In addition, empirical investigations of various sectors including the airline industry have provided convincing evidence that the "national champion" model rarely works, and it is competition that brings innovation and improvements in the long term. Even if the Chinese government still follows the "national champion" strategy in the coming years, a 
more deregulated market would encourage Chinese airlines to compete, as they are now among the largest airlines in the world (shown in Table 4). Few industries, including the airline sector, can become globally competitive through government protection. The Japanese government had for decades given its "national carriers" direct and indirect assistance, but JAL still filed for bankruptcy protection in 2009. More competition has since been introduced in the Japanese domestic and international markets, yet JAL has recently emerged as a stronger airline. Therefore, we believe that the three countries in the NEA region should liberalize their skies to maximize the benefits to the overall economy, instead of continuing the strategy of protecting their airlines.

Policy and political considerations may still override economic considerations, however, and NEA governments may not change their policies immediately. Major airlines may continue to significantly influence liberalization policies. In this section, we identify the opportunities and challenges of liberalization for the major airlines of the region, so as to identify their preferences and strategies. This will enable us to predict the likely liberalization processes in the short term, assuming public policies remain influenced by major airlines over the next few years. However, compared to full liberalization, this is obviously not the most favorable outcome.

\subsection{Priority markets and airline performances}

The three countries in NEA have experienced strong growth in economy and international trade at different times. By the 1980s, Japan's economy was strong with high export levels. In the aviation industry, priority was given to the development of North American routes, with both Japanese and US carriers establishing good networks and high frequency services to the United States. The Korean economy and aviation industry developed in a similar way, with major liberalization agreements signed between Korea and the US after the Asian financial crisis. In comparison, although trade and passenger volumes between China and the US have been growing quickly since the early 1990s, the North American network of China's airlines was far behind their Japanese and Korean counterparts. Table 6 shows that in 2001 three Chinese carriers served three North American destinations with 23 weekly flights. Japanese (and Korean) airlines served 10 (and 11) destinations with 198 (and 92) weekly flights in the same year. Chinese carriers have since developed their networks, and as of July 2014, the numbers of North American destinations and weekly frequencies of Chinese carriers had reached those of their Japanese and Korean competitors. There are, however, more Chinese carriers serving this market than Japanese and Korean (two airlines each), thus that the service of individual Chinese airlines is still likely to be inferior.

\section{$<$ Table 6 here>}

Geographic location and airport capacity are also important in determining the competition among NEA carriers for services to North America. Without an open-skies agreement between China and the US, a regional NEA open-skies agreement would enable Japanese and Korean carriers to use Tokyo and Incheon as gateway hubs to North America. Indeed, many Chinese passengers are now taking connection flights from Seoul. 
Table 7 shows that network connectivity of Chinese carriers to European destinations is generally better than the connectivity of other NEA airlines in terms of airports served, weekly frequency, and number of seats offered within our sample period from 2001 to 2014. In terms of geographic location and market potential, major Chinese airports such as Guangzhou, Chengdu, and Xi' an may serve as Asian gateway hubs to Europe. Guangzhou airport has a large capacity and a rapidly growing local market, so it is well positioned to compete with other Asian hubs such as Bangkok, Singapore, or even Dubai in the long term. China Southern has been making good progress in developing the "Canton route" via the Guangzhou airport, which could potentially feed traffic from Southeast Asia, Australia, and New Zealand to its European services. China Southern may also be able to capture a share of the traffic previously served by the "Kangaroo routes" linking Australia and New Zealand to Europe.

\section{$<$ Table 7 here $>$}

In terms of international network development in Asia and Oceania, Chinese and Korean airlines performed better than Japanese airlines. Table 8 shows that, in 2012 and 2014, Korean carriers served more destinations, whereas Chinese airlines provided more frequent services and more scheduled seats. Japanese carriers consistently lagged behind other NEA airlines. This is probably due to their high costs, which make them less competitive when serving relatively price-sensitive consumers. Japanese carriers also serve fewer Chinese cities than their Korean competitors. More investigations are needed to identify the main reasons why Japanese carriers have limited network coverage in Asia and Oceania.

\section{$<$ Table 8 here >}

In summary, Japanese and Korean carriers have better network coverage to destinations in North America, whereas Chinese airlines are better positioned for services to Europe. For aviation services to Asia and Oceania, Japanese airlines lag behind Chinese and Korean carriers. Chinese airlines are therefore likely to have the following preferences in aviation policy:

- Chinese airlines will be less resistant toward bilateral liberalization with ASEAN countries, Australia, and New Zealand, as a more liberal regional market will help Chinese airlines develop their hubs as gateways to Europe, currently Guangzhou and in the long term Chengdu, Other than Singapore Airlines and Qantas, few network carriers in these countries can compete with Chinese airlines for European destinations. Therefore, bilateral liberalization with these countries may not put too much competitive pressure on Chinese airlines, but will significantly help develop the connecting passenger markets between these countries and Europe.

- In the absence of open-skies agreements with the US and Canada, Chinese airlines may have some concerns about creating a single aviation market with Korea and Japan in the short term: Japanese and Korean carriers have good network coverage to North American destinations, allowing them to feed traffic from China and the rest of Asia to 
their gateway hubs in Incheon and Tokyo. There are many more airports in China than in Japan and Korea, so liberalization will bring network benefits to Japanese and Korean airlines, as they will be able to connect many more spoke markets to their hubs. Similar observations have been made by Lau et al. (2012). Their study found that when direct air services were allowed across the Taiwan Straits, airlines in Taiwan were able to improve their networks more than carriers in mainland China.

\subsection{Performance of major airports and effects on hub airlines}

Major airports can exert considerable influence over national liberalization policies. The connectivity and competitiveness of a major hub positively effects its hub carrier's development. The performances of major hubs in the NEA region are reported in Table 9. Unlike analysis in the above section on airlines, this table reports all the services of both domestic and foreign carriers.

< Table 9 here>

As evidenced in Table 9, for comparisons related to hub airports connectivity:

- The network connectivity of Japanese carriers in Asia and Oceania lagged behind their NEA competitors, but due to the frequent services of foreign carriers, Narita has comparable connectivity to most NEA hubs, except that of Incheon. Several factors have contributed to Incheon's superior network connectivity: the Korean government has actively promoted aviation liberalization in recent years, and their hub policy restricts international services to Seoul Gimpo airport. In the long term, relaxing this policy would allow more international LCC services at Gimpo. This issue will be discussed in Section 4.

- For European destinations, Beijing is far ahead of other hubs, with 24 airports connected via direct flights, followed by Narita (16), Incheon (14), Shanghai Pudong (12), and Guangzhou (5). With Beijing's large market potential and status as the national capital, this advantage is likely to continue for many years. Geographically Guangzhou Baiyun airport is in fact better positioned to serve as a European gateway. China Southern has made good progress in developing its "Canton routes" in recent years, although overall Guangzhou airport still has a long way to go. The airport may therefore be keen to support liberalization policies, which may allow more frequencies and destinations to be added by both domestic and foreign carriers.

- When foreign carriers' services are taken into account, airport development analysis is very different from that for major airlines. All three international hubs in China (Beijing capital airport, Shanghai Pudong airport, and Guangzhou Baiyun airport) have better connections to North America than Incheon and Narita in terms of number of destinations and weekly frequency. This probably explains why US carriers have hoped for bilateral liberalization with China, which will enable more destinations and frequencies to be added. The demand for passenger and cargo flow between the world's two largest economies is very high. Protecting home carriers in this market will not only prevent consumers from enjoying better services, but also prevent NEA airlines from optimizing their networks in the region. 


\subsection{Liberalization policy preferences of Chinese airlines and hub airports}

With on-going processes of airport privatization, commercialization and localization, major hubs will gain increasing attention from local and central governments. The strategy and preference of both major airlines and hub airports will therefore be taken into consideration when regulators design national aviation policies. A clear understanding of the strategies of airlines and airports (vested interests) will help us predict possible government aviation policies.

In terms of home carriers' performance and network connectivity, the services of Chinese airlines to North America are still slightly behind other NEA carriers. Geographic locations of Incheon and Narita airports have made them ideal gateways for traffic between Asia and North America. Regional liberalization among NEA countries will allow Japanese and Korean carriers to compete for the China - US routes by feeding traffic to their own hubs. The main Chinese airlines are therefore unlikely to be enthusiastic about such a liberalization policy. Instead, they may be less resistant to liberalization packages with the EU and the rest of Asia and Oceania. Their services are relatively well established for European destinations, and the airports of Guangzhou and Chengdu may be developed as gateways to Europe with more feeder routes from Asia and Oceania. Other than Singapore Airlines and Qantas, there are no other strong network carriers in the region. Therefore, if the Chinese government continues its support of major state-owned carriers, such as the "big three", liberalization with ASEAN countries, Oceania, and Europe will be more of a priority than creating a single aviation market in the NEA region.

When the services of foreign carriers are also taken into consideration, hub airports in Chinese metropolitan areas appear better positioned to become gateways to both Europe and Oceania than Incheon and Narita, and their competitiveness on North American routes also increases significantly. Recent studies suggest that the growth of dominant airlines, and vertical arrangements with airports, affect the equilibrium of aviation markets, leading to interactive dynamics between hub carrier performance and airport development (see Barbot, 2009; Fu and Zhang, 2010; Zhang et al., 2010; Fu et al., 2011; Homsombat et al., 2011; Yang et al., 2015, for example). This implies that Chinese carriers have not yet fully leveraged the market potential and domestic dominance at their hubs in order to develop international services. This has in turn prevented the hub airports from achieving their full potential. In comparison, Incheon airport has rapidly established itself as an important international gateway due to Korea's recent liberalization policies and the international expansion of the hub airlines. Although there are positive dynamics between major airports and their hub carriers, policies protecting home airlines may actually constrain rather than strengthen the competitiveness of airports. Chinese hub airports currently have limited influence on international aviation policy, but in the long term they will have more reasons to be supporters of liberalization.

In the short term, there is a strong likelihood that major airlines in the NEA region, particularly those in China, will continue to exercise significant influence over their nations' liberalization policies. We believe that governments should prioritize consumer well-being and national interests. One immediate strategy for encouraging liberalization is to promote LCC services in the region. The following section evaluates the possible effects of this policy option.

\section{Liberalization by facilitating low cost carrier services}

Most LCCs in the NEA region were created in the last couple of years, though some are long-established. Many new entrants in Korea and Japan are affiliated with incumbent network carriers. In certain markets, such ownership structures may help LCCs secure approval for route 
entry and airport slots. The study by Homsombat et al. (2014) into the Australian domestic market reveals that a "dual-brand" strategy, jointly offering network carrier services and LCC services, may bring competitive advantages to an airline group. However, such ownership/affiliation arrangements could lead to future complications, as network carriers may block the entry of foreign LCCs to undercut their parent airlines. Many LCCs have chosen to form local joint ventures when expanding their businesses in another country. Such a strategy has been adopted by AirAsia and Jetstar when entering markets such as Thailand, the Philippines, and Japan. Another strategy of overseas expansion is to serve foreign destinations under rules set by bilateral service agreements. In this section we will focus on the bilateral approach.

Promoting LCC services in the NEA region can be a good alternative to full liberalization in the medium term. To cut costs, LCCs usually provide no-frill point-to-point services in short/medium-distance markets. Connection services are normally not offered as they significantly increase baggage handling costs and turnaround time at airports. Improved LCC services do not therefore significantly affect the competition between network carriers on intercontinental routes. Whereas route entry and slot allocation at hub airports are closely monitored, regulators and major carriers are usually not concerned with the expansion of LCCs at regional airports. Fu et al. (2015) investigated the pricing and network development pattern of the largest LCC in China, Spring Airlines. They concluded that similar to LCCs in developed markets, Spring prefers to serve markets with high traffic volumes out of its operational base in Shanghai. However, in dense routes Spring's capacity and market share are constrained to low levels, likely due to government regulation, and/or a "puppy dog" strategy adopted by the carrier in order to earn profits without triggering a price war. In comparison, the carrier's market shares in relatively thin routes are significantly higher. In certain cases, the LCC initiated some new routes to small regional airports which had not been served by any airline before. Local governments welcome new services, which improve their airports' connectivity and contribute to the regional economy. The low cost base allows LCCs to serve thin markets, which are not feasible for network carriers. Disruption to the existing market equilibrium will be relatively moderate. Therefore, promoting LCC entry can be a feasible and useful first step toward full liberalization.

The profiles of NEA LCCs are summarized in Table 10. As of June 2014, most LCCs had less than 20 aircraft in service, giving them a relatively small market share. Table 11 also shows that NEA LCCs have mainly focused on the domestic market. Some serve a good number of international destinations (e.g. Spring Airlines in China, Jeju Air, Air Busan, Jin Air in Korea), but the low total frequencies reveal that these services are rather limited. LCCs could not therefore reduce costs by exploiting economies of traffic density. Both individual government regulations and bilateral service agreements impose limitations. For example, foreign LCC services are permitted mostly at the Incheon airport, even though the Seoul Gimpo airport has capacity and is closer to the city. The traffic rights allocated by the Korean Ministry of Land, Infrastructure and Transport (MOLIT) are ad hoc without clearly defined rules, making it difficult for LCCs to optimize and plan their service offerings.

\section{< Table 10 and Table 11 here>}

There are signs that China is progressively allowing foreign LCCs into both large and medium-sized airports. Table 12 shows that as of July 2014, foreign LCCs served 36 Chinese airports. Guangzhou, Hangzhou, Shenzhen, and Shanghai Pudong airports had the highest weekly LCC flights. Qingdao has 20 LCC flights a week, mainly due to the provincial openskies agreement signed between Korea and Shandong province, which allowed Korean carriers to offer 14 weekly flights to the city. Otherwise, Korean LCCs have quite limited services to 
China, despite direct flights to 22 airports. For example, eight airports were served with only one LCC flight per week as of July 2014. A closer look of the data revealed that these services were all recently initiated by Jin Air, an LCC owned by Korean Air. Therefore, more flights may be added in the near future, and the LCC may have been assisted by its affiliated network carrier (i.e. Korean Air) in entering these routes. No Japanese LCC services were available at Chinese airports, although Chinese LCCs served four medium sized Japanese airports (Hiroshima, Ibaraki, Saga, and Takamatsu) with a total of 18 weekly flights in July 2014.

\section{< Table 12 here>}

There are in general signs that China is progressively opening up its skies to foreign LCCs. A number of airports are now accessible, though services are still concentrated at a few airports for the time being. Several factors may have contributed to this: as discussed previously, LCCs usually do not provide connection services so will not contribute competitive advantages to their parent airlines (if any). Major Chinese network carriers will be less concerned about competition in the short term. The lower average costs and smaller aircraft used by LCCs suggest they are better positioned to serve medium-sized airports, which are usually not congested and of secondary importance to Chinese network carriers. Provincial and municipal governments will also welcome foreign LCC services, which benefit local airports, businesses, and social welfare. It should therefore be possible for foreign LCCs to significantly expand within non-hub Chinese airports in the future.

The open-skies agreement between Korea and Japan has led to their LCCs having reasonably good network coverage in each other's territory. For example, Japanese LCCs have five daily flights (35 weekly flights) to Incheon and one daily flight to Busan. Korean LCCs have frequent services to major airports such as Kansai, Narita, Fukuoka and Nagoya, and to five other regional airports. Compared to China, international and domestic LCC services are better developed in Japan and Korea, although LCC penetration rates are still behind other Asian markets such as Malaysia, Singapore, and Australia. Some constraints to further development should be removed; for example, the Seoul Gimpo airport is close to the city center and has convenient ground transport systems, but in 2001, all international services were relocated to Incheon airport, causing a $40 \%$ reduction in passenger volume almost overnight. Other than a few routes such as Seoul - Jeju Island, domestic aviation markets have achieved little growth over the years, due to competition from high-speed rail services. To revive its business, Gimpo has been reducing operation costs and trying to improve its non-aeronautical services. In addition, some regional flights to Japan, China, and Taiwan have been reintroduced along with services such as customs, immigration, and quarantine (CIQ). Seoul Gimpo airport is ideal for all types of international services. Currently, however, the Korean government has not allocated any traffic rights to foreign LCCs at Gimpo, even though there is no congestion or slot constraint. The Ministry's misguided policy of promoting Seoul-Incheon airport as the only hub is preventing Seoul-Gimpo from fully realizing its market potential. It is our view that government regulations and intervention such as this should be removed, enabling airlines to optimize their operations in a deregulated environment.

\section{Summary, Conclusion, and further Thought}

The benefits of air transport liberalization have been confirmed by many studies. However, much of the NEA market remains regulated, despite strong economic growth and increased international trade in the region, along with completion of trans-border open-skies agreements. Governments should aim to improve social welfare of their nations, and their economies as a 
whole, rather than aiding only those with vested interests, i.e., major network carriers. However, in practice the region's dominant airlines have exerted significant influences against liberalization. Investigations into the performance of major airlines will therefore help predict their strategies for developing internationally, and their attitudes toward alternative liberalization policies. An examination of legacy regulations in domestic markets also provides insight into policy priorities and philosophies of regulators in international markets. The implication is clear: if certain regulations have been persistent in the domestic markets, they are unlikely to be removed for foreign carriers in the near future.

Our investigation into the NEA aviation markets, particularly China, reveals that substantial legacy regulations are still present in the Chinese domestic market, despite rapid growth of the aviation industry in the past decades. Specifically, our examination leads us to the following conclusions:

- In the Chinese aviation market, dominant carriers are majority-owned and managed by either central or local governments. Supporting services and inputs are also controlled by state-owned companies with significant market power. The central government owns the largest three airline groups as well as the dominant/monopoly companies that provide fuelling services, ticketing and airport IT services, fleet purchasing and leasing services. The regulator has shown little concern over market consolidation and competition. Only a few private airlines have been allowed to enter the market, and they are still much smaller than their state-owned peers.

- The regulations on route entry and airport slot allocation in China provide preferential treatment to dominant carriers, making it difficult for other airlines to compete in major hubs, which account for a significant share of the Chinese market. There is evidence that dominant airlines have improved their hub-and-spoke networks, but there are also signs that precious airport slots have not been allocated in an efficient manner.

In summary, the Chinese government has attempted to help major airlines grow in size, rather than forcing them to improve and innovate through increased competition and thus achieve global competitiveness. Chinese airlines have not bridged the efficiency gaps among global leaders. Hub airports could have enjoyed better aviation services and network connectivity if more liberalization policies had been introduced.

Chinese airlines are currently more competitive in providing services to destinations in Europe, Asia, and Oceania than to North America destinations. They will therefore be more open to liberalization agreements with these countries, and develop their hubs into Asia's gateways to Europe. In general, however, there is no sign that these dominant airlines will welcome complete liberalization. As an intermediate compromise (in place of an optimal policy in the long term), promoting LCC services in the NEA region is a practical policy. Liberalizing LCC services will not significantly influence competition between network carriers on intercontinental routes. Whereas route entry and slot allocation at hub airports are closely monitored, regulators and major carriers are not particularly concerned with the expansion of LCCs at regional airports. Local governments also welcome new services, which improve their airports' connectivity and contribute to the regional economy. Therefore, promoting LCC entry can be a feasible and useful first step toward full liberalization.

In the longer term, however, there is a need to fully liberalize the aviation markets in the region. The priority of governments should be to maximize the welfare of the nation as a whole, rather than just protecting the airlines. Adler et. al (2014) modeled transport market in Northeast Asia using an airline network model. They found that air transport liberalization would benefit both consumers and the aviation industry in the region albeit not necessarily on 
an equal basis across or within groups. They also noted that airport slot allocation policies play an important role in the realization and distribution of potential welfare gains related to liberalization. Therefore, government agencies should implement liberalization and airport slot allocation policies jointly. Studies in the airline sector, together with lessons learned in other industries, have also shown that a "national-champion" strategy rarely works. It is increased competition that forces airlines to improve and innovate, leading to global competitiveness and sustain long-term growth.

As discussed, Korean and Japanese governments, and to some extent their transport ministry officials, now realize that opening up the air transport market in the Northeast Asian region is an important economic issue. However, the current dominant players in China's air transport sector, somewhat helped by the CAAC's regulations, have restricted domestic competition and foreign carrier entries, particularly services to airports in the metropolitan areas of Beijing, Shanghai, and Guangzhou. This policy is likely to continue until one or more of the following happens:

- A shift in attitudes of Chinese leaders and elites towards supporting liberalization: China's three major carriers are now among the largest carriers in Asia, and are on their way to becoming the largest carriers in the world within this decade. ${ }^{5}$ Policies designed to protect them are akin to 'treating giants as babies,' which makes little sense. Unless CAAC's senior officers and bureaucrats realize this soon, it will become apparent to China's economic leaders and elites, and perhaps even the state leaders, that this is a wrong air transport policy, which can harm China's economy and ordinary citizens.

- Informed policy changes: In the next few years, Korea and/or Japan may add the issue of air transport to China-Korea, China-Japan and/or tripartite Economic Summit meetings agenda so that trade, investment, and air transport opportunities can be weighed up. Instead of postponing industry reform and restructuring for as long as possible, it is better for the transport ministry and CAAC officials to proactively design deregulation / liberalization policies with a clear road map. With informed policy changes ahead, the Chinese aviation sector can innovate and improve to achieve international competitiveness.

- Increasing pressure from private airlines and central government agencies: Over time, other central government agencies, together with local governments and airports, will see the opportunities that foreign carrier entries can bring, and help them achieve important political and economic objectives. Private airlines will request more freedom to operate and compete with state-owned carriers on an equal basis. There will be increased pressure for deregulation and liberalization.

The CAAC and major carriers in China may also want to open up markets to their Asian neighbors for their own benefit. Our reasoning on this is as follows:

- As already examined, China's major airlines and airports are well positioned to route European-bound Asian traffic via their major hubs in China (Beijing, Shanghai,

\footnotetext{
${ }^{5}$ The CAPA Center for Aviation (CAPA 2015) reported that China Southern Airlines carried more than 100 million passengers in 2014, marking the company the sixth airline group in the world to transport over 100 million passengers a year. The Air China and China Eastern groups are expected to cross the mark, with the HNA Group to carry 100 million passengers within 5 years. China is expected to have four groups with over 100 million passengers, matching the US.
} 
Guangzhou, Chengdu, etc.), including connecting traffic originating from or flying to Korea and Japan. With continued investments in airports and air traffic control systems, such as the planned second-airports in Beijing and Chengdu, more capacity will be available in the Chinese aviation system, facilitating its airlines and airports to expand internationally;

- With higher service frequencies from the current and future mega-hubs to intercontinental destinations (including North America and Europe) in the future, Chinese airlines can increasingly attract more overseas passengers from Japan and Korea to connect via Chinese hub airports. When China's air travel propensity increases to 0.75 per capita, its air transport market will exceed that of the United States. By then China's mega-hubs are likely to assume similar roles in Asia to those of Chicago, Atlanta, and Dallas in the US, offering a high frequency of services to major intercontinental destinations in Europe and North America.

The benefits of air transport liberalization have been confirmed by many studies examining mature markets. More investigations into the NEA aviation markets are needed so governments and regulators in the region can make informed decisions and commit to a clear road-map for liberalization. Air transport liberalization is a dynamic process. The development of airline markets is related to the economic growth that a region enjoys. Further, as the airline market develops, interest groups and stake-holders may favor a more open environment and press for liberalization. ${ }^{6}$ If regulators and major carriers in the region fully recognize the opportunities which may be realized within this decade, there can be a rational move by these power brokers to proactively push for liberalization, instead of trying to kick the can down the road as long as possible.

\section{References:}

Adler, N., Fu, X., Oum, T.H., Yu, C., 2014. Air transport liberalization and airport slot allocation: the case of the Northeast Asian transport market. Transp. Res. Part A 62, 319.

Audretsch, D. B., Yamawaki, H., 1988. R\&D rivalry, industrial policy, and U.S.-Japanese trade. Rev. of Econ. and Stat. 70(3), 438-447.

Barbot, C., 2009. Airport and airline competition: incentives for vertical collusion. Transp. Res. Part B 43(10), 952-965.

Borenstein, S., 1989. Hubs and high fares: dominance and market power in the U.S. airline industry. RAND J. of Econ. 20, 344-365.

Brueckner, J.K., 2009. Price vs. quantity-based approaches to airport congestion management. J. of Public Econ. 93(5), 681-690.

CAPA Center for Aviation (CAPA), 2015. China Southern 6th airline in history to carry over $100 \mathrm{~m}$ passengers, now for improved efficiency. CAPA News, retrieved in Feb 2015 at http://centreforaviation.com/analysis/china-southern-6th-airline-in-history-to-carryover-100m-passengers-now-for-improved-efficiency-203547

Chou, T.-C., 1986. Concentration, profitability and trade in a simultaneous equation analysis: the case of Taiwan. The J. of Indus. Econ. 34(4), 429-443.

Clark, D. P., Kaserman, D. J., Melese, F., 1992. Domestic market structure and international trade in an open economy. Quarterly Rev. of Econ. and Finance 32(3), 3-15.

\footnotetext{
${ }^{6} \mathrm{We}$ are grateful to an anonymous referee who provided this comment to us.
} 
Clougherty, J., Zhang, A., 2009. Domestic rivalry and export performance: theory and evidence from international airline markets. Canadian J. of Econ. 42, 440-468.

DOT (U.S. Department of Transportation), 2001. Dominated hub fares. Domestic Aviation Competition Series.

DotEcon Ltd., 2001. Auctioning airports slots. London, UK.

DotEcon Ltd., 2006. Alternative allocation mechanisms for slots created by new airport capacity. London, UK.

FAA (U.S. Federal Aviation Administration), 1999. Airport business practices and their impact on airline competition. FAA / OST Taskforce Study.

Fu, X., Homsombat, W., Oum, T.H., 2011. Airport-airline vertical relationships, their effects and regulatory policy implications. J. Air Transp. Manage. 17, 347-353.

Fu, X., Lei, Z., Wang, K. and Yan, J., 2015. Low cost carrier competition and route entry in an emerging but regulated aviation market - the case of China. Transp. Res. Part A, forthcoming.

$\mathrm{Fu}, \mathrm{X} .$, Oum, T.H., 2014. Air transport liberalization and its effects on airline competition and traffic growth - an overview. Advances in Airline Economics 4, Editor: James H. Peoples, Jr.

Fu, X., Oum, T.H., Zhang, A., 2010. Air transport liberalization and its impacts on airline competition and air passenger traffic. Transp. J. 49(4), 24-41.

$\mathrm{Fu}, \mathrm{X}$., Zhang, A., 2010. Effects of airport concession revenue sharing on competition and social welfare, J. Transp. Econ. and Policy 44 (2), 119-138.

Fu, X., Zhang, A., Lei, Z., 2012. Will China's airline industry survive the entry of high-speed rail? Res. in Transp. Econ. 35, 13-25.

GAO (U.S. General Accounting Office), 1989. Barriers to competition in the airline industry.

GAO (U.S. General Accounting Office), 1990. Airline competition: industry operating and marketing practices limit market entry.

Homsombat W., Lei, Z., Fu, X., 2011. Development status and prospects for aviation hubs - a comparative study of the major airports in South-east Asia. Singapore Econ. Rev. 56(4), 573-591.

Homsombat, W., Lei, Z., Fu, X., 2014. Competitive effects of the airlines-within-airlines strategy - pricing and route entry patterns. Transp. Res. Part E 63, 1-16.

Hooper, P., 1998. Airline competition and deregulation in developed and developing country contexts - Australia and India. J. of transp. Geogr. 6(2), 105-116.

Hooper, P., 2014. Has liberalisation stalled? J. Air Transp. Manage. 41, 17-21.

Hooper, P., Hutcheson, S., Nyathi M., 1996. The challenge of liberalising domestic airline competition in a less developed country. Transportation 23, 395-408.

International Civil Aviation Organization (ICAO), 2013. Liberalization of market access, Working Paper, ATConf/6 reference material available at www.icao.int/meetings/atconf6

Kim, D., Marion, B.W., 1997. Domestic market structure and performance in global markets: theory and empirical evidence from U.S. food manufacturing industries. Rev. of Indus. Org. 12, 335-354.

Krugman, P. R., 1984. Import protection as export promotion: international competition in the presence of oligopoly and economies of scale' in Kierzkowski, H. (ed.), Monopolistic Competition and International Trade, Oxford University Press, Oxford.

Lau, Y.Y., Lei, Z., Fu, X., Ng, A., 2012. The implications of the re-establishment of direct links across the Taiwan Strait on the aviation industries in Greater China. Res. In Transp. Econ. 35, 3-12.

Lykotrafiti, A.A., 2008. State aid and air transport - a turbulent story, PhD thesis, King's College London. 
Madas, M.A., Zografos , K.G., 2006. Airport slot allocation: from instruments to strategies. J. Air Transp. Manage. 12(2), 53-62.

Madas, M.A., Zografos, K.G., 2008. Airport capacity vs. demand: mismatch or mismanagement? Transp. Res. Part A 42(1), 203-226.

Madas, M.A., and Zografos, K.G., 2010. Airport slot allocation: a time for change? Transp. Policy 17(4), 274-285.

Maldoom, D., 2003. Auctioning capacity at airports. Utilities Policy 11(1), 47-51.

Marvel, H. P., 1980. Foreign trade and domestic competition. Econ. Inquiry 18(1), 103-122.

Matthews, B., Menaz, B., 2003. Airport capacity: the problem of slot allocation. Institute for Transport Studies.

National Economic Research Associates (NERA), 2004. Study to assess the effects of different slot allocation schemes. Technical Report prepared for the European Commission (DG TREN), London, UK.

Piermartini, R., Rousova, L., 2008. Liberalization of air transport services and passenger traffic. World Trade Organization - Economic Research and Statistics Division, Staff Working Paper ERSD-2008-06.

Pagoulatos, E., Sorensen, R., 1976. Domestic market structure and international trade: an empirical analysis. Quarterly Rev. of Econ. and Business 16(1), 45-59.

Porter, M. E., 1990. The competitive advantage of nations. The Free Press, New York.

Sakakibara, M., Porter, M. E., 2001. Competing at home to win abroad: evidence from Japanese industry. Rev. of Econ. and Stat. 83(2), 310-322.

Sentance, A., 2003. Airport slot auctions: desirable or feasible? Utilities policy 11(1), 53-57.

Verhoef, E.T., 2010. Congestion pricing, slot sales and slot trading in aviation. Transp. Res. Part B 44(3), 320-329.

Wang, K., Fan X., Fu X., Zhou Y., 2014a. Benchmarking the performance of Chinese airlines: an investigation of productivity, yield, and cost competitiveness. J. Air Transp. Manage. 38, 3-14.

Wang, K., Gong Q., Fu X., Fan X., 2014b. Frequency and aircraft size dynamics in a concentrated growth market: the case of the Chinese domestic market. J. Air Transp. Manage. 36, 50-58.

Yang, H., Zhang A., Fu X., 2015. Determinants of airport-airline vertical arrangements: analytical results and empirical evidence, J. Transp. Econ. and Policy, forthcoming.

Zhang, A., Fu, X. and Yang G., 2010. Revenue sharing with multiple airlines and airports. Transp. Res. Part B 44(8-9), 944-959.

Zhang, Q., Yang, H., Wang, Q., 2013. Market conduct of the three busiest airline routes in China. J. Transp. Econ. and Policy 47, 335-347.

Zhang, Q., Yang, H., Wang, Q., Zhang, A., 2014. Market power and its determinants in the Chinese airline industry. Transp. Res. Part A 64, 1-13. 
Table 1. Airport Slot Control and Coordination at Selected Chinese Airports

\begin{tabular}{|c|c|c|c|}
\hline Airport & $\begin{array}{c}\text { Peak-hour } \\
\text { Movement } \\
\text { Limit (per hour) }\end{array}$ & $\begin{array}{c}\text { Coordinated } \\
\text { Time Period }\end{array}$ & $\begin{array}{c}\text { Effective } \\
\text { Since }\end{array}$ \\
\hline Beijing & 88 & $06: 00-02: 00$ & 2011.12 .15 \\
Shanghai Pudong & 65 & $06: 00-02: 00$ & 2010.5 .1 \\
Guangzhou & 58 & $06: 00-02: 00$ & 2010.3 .28 \\
Xi'an & 45 & $06: 00-02: 00$ & 2012.5 .7 \\
Shanghai Hongqiao & 43 & $06: 00-02: 00$ & 2010.5 .1 \\
Chongqing & 42 & $06: 00-02: 00$ & 2012.5 .25 \\
Shenzhen & 34 & $06: 00-02: 00$ & 2011.2 .9 \\
Chengdu & 34 & $06: 00-02: 00$ & 2012.3 .25 \\
Wuhan & 33 & $06: 00-02: 00$ & 2012.3 .25 \\
Hangzhou & 31 & $06: 00-02: 00$ & 2012.3 .25 \\
Nanjing & 28 & $06: 00-02: 00$ & 2012.3 .25 \\
Qingdao & 28 & $06: 00-02: 00$ & 2012.3 .25 \\
Xiamen & 28 & $06: 00-02: 00$ & 2011.2 .9 \\
Dalian & 27 & $06: 00-02: 00$ & 2012.5 .25 \\
Changsha & 27 & $06: 00-02: 00$ & 2011.2 .9 \\
Haikou & 27 & $06: 00-02: 00$ & 2011.2 .9 \\
Urumqi & 25 & $08: 00-04: 00$ & 2011.8 .15 \\
Tianjin & 24 & $06: 00-02: 00$ & 2011.1 .13 \\
Fuzhou & 23 & $06: 00-02: 00$ & 2011.2 .9 \\
Sanya & 20 & $06: 00-02: 00$ & 2011.2 .9 \\
\hline
\end{tabular}

Source: Compiled by the authors 
Table 2. Market Shares of the Top-10 Chinese Airports

\begin{tabular}{|c|c|c|c|c|c|c|}
\hline \multicolumn{7}{|c|}{ Market Share by Passenger Volume (Unit \%) } \\
\hline Year & 09 Rank & 2009 & 2008 & 2005 & 2002 & 1998 \\
\hline Beijing & 1 & 13.45 & 13.79 & 14.42 & 15.85 & 15.23 \\
\hline Guangzhou & 2 & 7.62 & 8.24 & 8.28 & 9.34 & 10.92 \\
\hline Shanghai / Pudong & 3 & 6.57 & 6.7 & 8.32 & 6.45 & N/A \\
\hline Shanghai / Hongqiao & 4 & 5.16 & 5.64 & 6.26 & 7.98 & 12.05 \\
\hline Shenzhen & 5 & 5.04 & 5.27 & 5.73 & 5.46 & 4.53 \\
\hline Chengdu & 6 & 4.66 & 4.25 & 4.89 & 4.40 & 3.86 \\
\hline Kunming & 7 & 3.90 & 3.91 & 4.16 & 4.14 & 4.33 \\
\hline Xi'an & 8 & 3.15 & 2.94 & 2.79 & 2.59 & 2.52 \\
\hline Hangzhou & 9 & 3.07 & 3.12 & 2.85 & 2.26 & 2.00 \\
\hline Chongqing & 10 & 2.89 & 2.75 & 2.33 & 2.26 & 2.07 \\
\hline Total & & 55.51 & 56.61 & 60.03 & 60.73 & 57.51 \\
\hline \multicolumn{7}{|c|}{ Market Share by Cargo Volume (Unit \%) } \\
\hline Year & 09 Rank & 2009 & 2008 & 2005 & 2002 & 1998 \\
\hline Shanghai / Pudong & 1 & 26.9 & 29.5 & 29.3 & 15.8 & N/A \\
\hline Beijing & 2 & 15.6 & 15.5 & 12.4 & 15.7 & 17.7 \\
\hline Guangzhou & 3 & 10.1 & 7.8 & 9.5 & 12.4 & 14.1 \\
\hline Shenzhen & 4 & 6.4 & 6.8 & 7.4 & 7.2 & 4.0 \\
\hline Shanghai / Hongqiao & 5 & 4.6 & 4.7 & 5.7 & 10.9 & 19.8 \\
\hline Chengdu & 6 & 4.0 & 4.2 & 4.0 & 4.0 & 3.8 \\
\hline Kunming & 7 & 2.7 & 2.7 & 3.1 & 3.0 & 3.5 \\
\hline Hangzhou & 8 & 2.4 & 2.4 & 2.6 & 2.2 & 1.9 \\
\hline Nanjing & 9 & 2.1 & 2.1 & 2.2 & 1.3 & 1.1 \\
\hline Xiamen & 10 & 2.1 & 2.2 & 2.5 & 2.7 & 3.3 \\
\hline Total & & 76.92 & 77.9 & 78.70 & 75.20 & 69.20 \\
\hline
\end{tabular}

Note: Shanghai Pudong International Airport was in service on 1 Oct 1999

Source: Fu et al. (2012) 
Table 3.1 Average aircraft size on routes between different sized airports

\begin{tabular}{|l|c|c|c|}
\hline \multicolumn{5}{|c|}{2002} \\
\hline Top 10 airports & $182(33.14)$ & $148(35.92)$ & $113(49.30)$ \\
\hline Airports ranked 11-50 & & $123(48.69)$ & $91(55.66)$ \\
\hline Other airports & \multicolumn{3}{|c|}{2008} \\
\hline \multicolumn{5}{|c|}{ Top 10 airports } & Airports ranked 11-50 & Other airports \\
\hline \multicolumn{5}{|c|}{ Top 10 airports } & $166(32.05)$ & $146(21.48)$ & $115(43.82)$ \\
\hline Airports ranked 11-50 & & $134(38.44)$ & $100(51.40)$ \\
\hline Other airports & & & $85(55.26)$ \\
\hline
\end{tabular}

Note: Numbers in parentheses are standard deviations.

Source: Wang et al. (2014b)

Table 3.2 Weekly average flight frequency on routes between different-sized airports

\begin{tabular}{|l|c|c|c|}
\hline \multicolumn{5}{|c|}{2002} \\
\hline Top 10 airports & Airports ranked 11-50 & Other airports \\
\hline Airports ranked 11-50 & $78.5(61.67)$ & $26.8(27.62)$ & $6.6(8.30)$ \\
\hline Other airports & \multicolumn{3}{|c|}{2008} \\
\hline \multicolumn{5}{|c|}{ Toirports } & $9.1(9.20)$ & $7.9(9.68)$ \\
\hline & Top 10 airports & Airports ranked 11-50 & Other airports \\
\hline Top 10 airports & $168.6(104.41)$ & $50.2(48.71)$ & $10.6(14.31)$ \\
\hline Airports ranked 11-50 & & $14.8(16.10)$ & $8.6(12.73)$ \\
\hline Other airports & & & $10.9(16.59)$ \\
\hline
\end{tabular}

Note: Numbers in parentheses are standard deviations.

Source: Wang et al. (2014b) 
Table 4. Benchmark Major Airlines' Performance in NEA

\begin{tabular}{|c|c|c|c|c|c|c|c|}
\hline 2001 & $\begin{array}{c}\text { China } \\
\text { Southern } \\
\end{array}$ & $\begin{array}{c}\text { China } \\
\text { Eastern } \\
\end{array}$ & Air China & $\begin{array}{c}\text { Korean } \\
\text { Air } \\
\end{array}$ & Asiana & $\begin{array}{c}\text { Japan } \\
\text { Air }\end{array}$ & ANA \\
\hline Total Revenue (million US\$ current price) & 2,039 & 1,468 & 2,747 & 4,393 & 1,718 & 12,095 & N/A \\
\hline Total Profit (million US\$ current price) & 169 & 69 & 115 & 718 & 344 & -276 & N/A \\
\hline Revenue Passenger $(1,000)$ & 19,121 & 10,371 & 15,600 & 21,638 & 11,931 & 37,183 & N/A \\
\hline Number of Aircraft & 111 & 70 & 114 & 127 & 59 & 173 & N/A \\
\hline$\%$ of Cargo Revenue & $8 \%$ & $17.20 \%$ & $15 \%$ & $27.81 \%$ & $28.24 \%$ & $14.90 \%$ & N/A \\
\hline$\%$ of International RPK & $22.40 \%$ & $\mathrm{~N} / \mathrm{A}$ & $46 \%$ & $88.67 \%$ & $84.21 \%$ & $77.23 \%$ & N/A \\
\hline 2006 & $\begin{array}{c}\text { China } \\
\text { Southern }\end{array}$ & $\begin{array}{c}\text { China } \\
\text { Eastern }\end{array}$ & Air China & $\begin{array}{c}\text { Korean } \\
\text { Air } \\
\end{array}$ & Asiana & $\begin{array}{c}\text { Japan } \\
\text { Air }\end{array}$ & ANA \\
\hline Total Revenue (million US\$ current price) & 5,797 & 4,842 & 5,636 & 8,455 & 3,613 & 19,499 & 11,769 \\
\hline Total Profit (million US\$ current price) & 26 & -433 & 415 & 1,856 & 706 & -138 & 230 \\
\hline Revenue Passenger $(1,000)$ & 49,206 & 35,040 & 33,971 & 22,353 & 12,767 & 57,452 & 49,609 \\
\hline Number of Aircraft & 309 & 205 & 225 & 116 & 65 & N/A & N/A \\
\hline$\%$ of Cargo Revenue & $7.70 \%$ & $15 \%$ & $9 \%$ & $31.36 \%$ & $27.68 \%$ & $9.50 \%$ & $6.21 \%$ \\
\hline$\%$ of International RPK & $17 \%$ & $37.80 \%$ & $48.00 \%$ & $92.85 \%$ & $91.50 \%$ & $65.35 \%$ & $32.10 \%$ \\
\hline 2012 & $\begin{array}{c}\text { China } \\
\text { Southern }\end{array}$ & $\begin{array}{c}\text { China } \\
\text { Eastern }\end{array}$ & Air China & $\begin{array}{c}\text { Korean } \\
\text { Air }\end{array}$ & Asiana & $\begin{array}{c}\text { Japan } \\
\text { Air }\end{array}$ & ANA \\
\hline Total Revenue (million US\$ current price) & 15,771 & 13,511 & 15,981 & 10,883 & 5,003 & 14,509 & 16,998 \\
\hline Total Profit (million US\$ current price) & 808 & 445 & 781 & 1,238 & 598 & 2,247 & 339 \\
\hline Revenue Passenger $(1,000)$ & 86,485 & 73,077 & 72,416 & 24,283 & 15,514 & 37,564 & 44,903 \\
\hline Number of Aircraft & 491 & 428 & 461 & 142 & 71 & 216 & 230 \\
\hline$\%$ of Cargo Revenue & $6.60 \%$ & $10.10 \%$ & $8.40 \%$ & $25.27 \%$ & $25.73 \%$ & $6.54 \%$ & $8.59 \%$ \\
\hline$\%$ of International RPK & $20.80 \%$ & $30.20 \%$ & $33.30 \%$ & $96.19 \%$ & $94.94 \%$ & $89.64 \%$ & $42.30 \%$ \\
\hline
\end{tabular}

Source: Company's annual reports and industry sources 
Table 5. Gross Total Factor Productivity (TFP) Index of Major Airlines (Normalized at American Airlines 2005=1)

\begin{tabular}{|c|c|c|c|c|c|c|c|c|c|c|c|c|c|c|c|c|}
\hline Year & $\begin{array}{c}\text { China } \\
\text { Eastern }\end{array}$ & $\begin{array}{c}\text { China } \\
\text { Southern }\end{array}$ & $\begin{array}{c}\text { Air } \\
\text { China }\end{array}$ & $\begin{array}{c}\text { Chinese } \\
\text { A.V.G }\end{array}$ & $\begin{array}{c}\text { Thai } \\
\text { Airways }\end{array}$ & Singapore & Cathay & American & Delta & United & Continental & $\begin{array}{c}\text { Air } \\
\text { Canada }\end{array}$ & $\begin{array}{c}\text { North } \\
\text { American } \\
\text { A.V.G } \\
\end{array}$ & Lufthansa & $\begin{array}{c}\text { Air } \\
\text { France }\end{array}$ & KLM \\
\hline 2001 & 0.49 & 0.51 & 0.50 & 0.50 & 0.68 & 1.12 & 1.04 & 0.72 & 0.77 & 0.79 & 0.88 & 0.76 & 0.78 & 0.64 & & 0.85 \\
\hline 2002 & 0.50 & 0.54 & 0.53 & 0.52 & 0.73 & 1.01 & 1.17 & 0.74 & 0.81 & 0.92 & 0.86 & 0.79 & 0.82 & 0.67 & 0.71 & 0.83 \\
\hline 2003 & 0.49 & 0.50 & 0.54 & 0.51 & 0.66 & 1.01 & 1.11 & 0.85 & 0.89 & 0.99 & 0.98 & 0.80 & 0.91 & 0.65 & 0.75 & 0.82 \\
\hline 2004 & 0.60 & 0.56 & 0.63 & 0.60 & 0.70 & 1.01 & 1.10 & 0.94 & 0.86 & 1.07 & 0.96 & 0.95 & 0.95 & 0.70 & 0.77 & 0.94 \\
\hline 2005 & 0.56 & 0.57 & 0.68 & 0.61 & 0.70 & 1.10 & 1.10 & 1.00 & 1.01 & 1.11 & 0.99 & 0.91 & 1.01 & 0.72 & 0.89 & 0.89 \\
\hline 2006 & 0.59 & 0.61 & 0.75 & 0.65 & 0.74 & 1.29 & 1.05 & 1.04 & 1.06 & 1.15 & 1.03 & 0.92 & 1.05 & 0.71 & 0.88 & 0.88 \\
\hline 2007 & 0.63 & 0.66 & 0.76 & 0.69 & 0.78 & 1.32 & 1.03 & 1.05 & 1.01 & 1.14 & 1.06 & 0.94 & 1.05 & 0.74 & 0.90 & 0.90 \\
\hline 2008 & 0.60 & 0.67 & 0.64 & 0.64 & 0.68 & 1.32 & 1.02 & 0.98 & 0.75 & 0.98 & 1.05 & 0.95 & 0.93 & 0.74 & 0.92 & 0.92 \\
\hline 2009 & 0.62 & 0.68 & 0.75 & 0.69 & 0.74 & 1.33 & 1.10 & 1.02 & 1.03 & 1.12 & 1.09 & 0.91 & 1.04 & 0.71 & 0.95 & 0.95 \\
\hline 2010 & 0.71 & 0.72 & 0.77 & 0.74 & 0.86 & 1.30 & 1.11 & 1.06 & 1.09 & 1.09 & 1.09 & 1.00 & 1.07 & 0.74 & 0.95 & 0.95 \\
\hline
\end{tabular}

Note: 1. United Airlines and Continental Airlines merged in 2010. Thus the TFP for the two airlines in 2010 is for the new merged airline.

2. Air France and KLM merged in 2005. Thus the TFP for the two airlines from 2005 to 2010 are for the new merged airline.

3. The weight used to calculate the Chinese and North American average TFP is the airlines' revenue share.

Source: Wang et al. (2014a) 
Table 6. NEA Airline Service to North American Destinations

\begin{tabular}{|c|c|c|c|}
\hline 2001 & Chinese Carriers & Japanese Carriers & Korean Carriers \\
\hline \# of Airports & 3 & 10 & 11 \\
\hline Weekly Frequency & 23 & 198 & 92 \\
\hline Weekly Seats & 8,008 & 69,771 & 31,809 \\
\hline \# Airlines & 3 & 3 & 2 \\
\hline 2006 & Chinese Carriers & Japanese Carriers & Korean Carriers \\
\hline \# of Airports & 4 & 9 & 11 \\
\hline Weekly Frequency & 47 & 145 & 100 \\
\hline Weekly Seats & 14,252 & 47,104 & 34,410 \\
\hline \# Airlines & 3 & 4 & 2 \\
\hline 2012 & Chinese Carriers & Japanese Carriers & Korean Carriers \\
\hline \# of Airports & 7 & 8 & 12 \\
\hline Weekly Frequency & 87 & 147 & 140 \\
\hline Weekly Seats & 24,981 & 39,186 & 45,049 \\
\hline \# Airlines & 5 & 3 & 2 \\
\hline 2014 & Chinese Carriers & Japanese Carriers & Korean Carriers \\
\hline \# of Airports & 11 & 11 & 13 \\
\hline Weekly Frequency & 154 & 189 & 152 \\
\hline Weekly Seats & 42,412 & 41,446 & 47,455 \\
\hline \# Airlines & 5 & 2 & 2 \\
\hline Source: OAG & 546 & & \\
\hline
\end{tabular}

Source: OAG database for scheduled flights

Note: The number of airports refers to the number of airports served with direct

flights. The first week of July in the sample year is referred for weekly statistics. 
Table 7. NEA Airline Service to European Destinations

\begin{tabular}{|c|c|c|c|}
\hline 2001 & Chinese Carriers & Japanese Carriers & Korean Carriers \\
\hline \# of Airports & 9 & 9 & 6 \\
\hline Weekly Frequency & 39 & 78 & 24 \\
\hline Weekly Seats & 11,426 & 26,919 & 8,904 \\
\hline \# Airlines & 3 & 2 & 2 \\
\hline 2006 & Chinese Carriers & Japanese Carriers & Korean Carriers \\
\hline \# of Airports & 12 & 8 & 10 \\
\hline Weekly Frequency & 96 & 79 & 53 \\
\hline Weekly Seats & 28,234 & 25,261 & 18,040 \\
\hline \# Airlines & 4 & 2 & 2 \\
\hline 2012 & Chinese Carriers & Japanese Carriers & Korean Carriers \\
\hline \# of Airports & 19 & 5 & 12 \\
\hline Weekly Frequency & 181 & 66 & 72 \\
\hline Weekly Seats & 44,823 & 21,232 & 23,859 \\
\hline \# Airlines & 4 & 2 & 2 \\
\hline 2014 & Chinese Carriers & Japanese Carriers & Korean Carriers \\
\hline \# of Airports & 20 & 7 & 12 \\
\hline Weekly Frequency & 219 & 88 & 23,778 \\
\hline Weekly Seats & 54,801 & 18,151 & 2 \\
\hline \# Airlines & 4 & 2 & \\
\hline Source: OAG & & & \\
\hline
\end{tabular}

Source: OAG database for scheduled flights

Note: The number of airports refers to the number of airports served with direct flights. The first week of July in the sample year is referred for weekly statistics. 
Table 8. NEA Airline Service to Destinations in Asia and Oceania (International markets only)

\begin{tabular}{|c|c|c|c|}
\hline 2001 & Chinese Carriers & Japanese Carriers & Korean Carriers \\
\hline \# of Airports & 43 & 25 & 55 \\
\hline Weekly Frequency & 735 & 471 & 454 \\
\hline Weekly Seats & 145,694 & 140,318 & 118,803 \\
\hline \# Airlines & 11 & 6 & 2 \\
\hline 2006 & Chinese Carriers & Japanese Carriers & Korean Carriers \\
\hline \# of Airports & 55 & 28 & 83 \\
\hline Weekly Frequency & 1,277 & 638 & 826 \\
\hline Weekly Seats & 235,298 & 166,689 & 214,628 \\
\hline \# Airlines & 8 & 5 & 2 \\
\hline 2012 & Chinese Carriers & Japanese Carriers & Korean Carriers \\
\hline \# of Airports & 78 & 30 & 97 \\
\hline Weekly Frequency & 2,036 & 669 & 1,526 \\
\hline Weekly Seats & 353,838 & 133,473 & 338,856 \\
\hline \# Airlines & 12 & 3 & 7 \\
\hline 2014 & Chinese Carriers & Japanese Carriers & Korean Carriers \\
\hline \# of Airports & 84 & 31 & 101 \\
\hline Weekly Frequency & 2,479 & 771 & 356,215 \\
\hline Weekly Seats & 436,846 & 165,452 & 7 \\
\hline \# Airlines & 14 & 4 & \\
\hline Source: OAG dab & & \\
\hline
\end{tabular}

Source: OAG database for scheduled flights

Note: The number of airports refers to the number of airports served with direct flights. The first week of July in the sample year is referred for weekly statistics. 
Table 9. Hub Airport Performance Benchmarking

\begin{tabular}{|c|c|c|c|c|c|c|}
\hline 2001 & $\begin{array}{c}\text { Shanghai } \\
\text { Pudong (PVG) }\end{array}$ & $\begin{array}{c}\text { Shanghai } \\
\text { Hongqiao (SHA) }\end{array}$ & Beijing (PEK) & $\begin{array}{c}\text { Guangzhou } \\
\text { (CAN) }\end{array}$ & Seoul (ICN) & Tokyo (NRT) \\
\hline Number of Asia-Oceania Destinations and weekly Frequency & $6 / 37$ & $19 / 268$ & $17 / 247$ & $14 / 94$ & $63 / 697$ & $33 / 529$ \\
\hline Number of European Destinations and weekly frequency & $5 / 27$ & - & $15 / 80$ & - & $8 / 46$ & $13 / 151$ \\
\hline $\begin{array}{l}\text { Number of North American Destinations and weekly } \\
\text { frequency }\end{array}$ & $4 / 30$ & - & $4 / 24$ & $1 / 4$ & $11 / 116$ & $18 / 345$ \\
\hline Other & - & - & $2 / 3$ & - & $1 / 2$ & $1 / 1$ \\
\hline 2006 & $\begin{array}{c}\text { Shanghai } \\
\text { Pudong (PVG) }\end{array}$ & $\begin{array}{c}\text { Shanghai } \\
\text { Hongqiao (SHA) }\end{array}$ & Beijing (PEK) & $\begin{array}{c}\text { Guangzhou } \\
\text { (CAN) }\end{array}$ & Seoul (ICN) & Tokyo (NRT) \\
\hline Number of Asia-Oceania Destinations and weekly Frequency & $38 / 750$ & - & $29 / 448$ & $20 / 221$ & $87 / 1126$ & $43 / 880$ \\
\hline Number of European Destinations and weekly frequency & $12 / 111$ & - & $16 / 147$ & $3 / 16$ & $10 / 81$ & $13 / 168$ \\
\hline $\begin{array}{l}\text { Number of North American Destinations and weekly } \\
\text { frequency }\end{array}$ & $5 / 45$ & - & $7 / 61$ & $1 / 7$ & $11 / 130$ & $19 / 341$ \\
\hline Other (Intl) & - & - & $4 / 15$ & $1 / 3$ & $2 / 11$ & $1 / 3$ \\
\hline 2012 & $\begin{array}{c}\text { Shanghai } \\
\text { Pudong (PVG) }\end{array}$ & $\begin{array}{c}\text { Shanghai } \\
\text { Hongqiao (SHA) }\end{array}$ & Beijing (PEK) & $\begin{array}{l}\text { Guangzhou } \\
\text { (CAN) }\end{array}$ & Seoul (ICN) & Tokyo (NRT) \\
\hline Number of Asia-Oceania Destinations and weekly Frequency & $48 / 985$ & $5 / 139$ & $41 / 656$ & $34 / 423$ & $101 / 1775$ & $48 / 935$ \\
\hline Number of European Destinations and weekly frequency & $16 / 190$ & - & $25 / 210$ & $11 / 66$ & $23 / 185$ & $26 / 271$ \\
\hline $\begin{array}{l}\text { Number of North American Destinations and weekly } \\
\text { frequency }\end{array}$ & $9 / 90$ & - & $10 / 106$ & $2 / 12$ & $13 / 175$ & $18 / 320$ \\
\hline Other (Intl) & $4 / 30$ & - & $11 / 58$ & $5 / 36$ & $5 / 32$ & $4 / 17$ \\
\hline 2014 & $\begin{array}{c}\text { Shanghai } \\
\text { Pudong (PVG) }\end{array}$ & $\begin{array}{c}\text { Shanghai } \\
\text { Hongqiao (SHA) }\end{array}$ & Beijing (PEK) & $\begin{array}{l}\text { Guangzhou } \\
(\mathrm{CAN})\end{array}$ & Seoul (ICN) & Tokyo (NRT) \\
\hline Number of Asia-Oceania Destinations and weekly Frequency & $56 / 1168$ & $6 / 136$ & $48 / 660$ & $39 / 449$ & $102 / 2009$ & $49 / 962$ \\
\hline Number of European Destinations and weekly frequency & $12 / 161$ & - & $24 / 210$ & $5 / 45$ & $14 / 145$ & $16 / 136$ \\
\hline $\begin{array}{l}\text { Number of North American Destinations and weekly } \\
\text { frequency }\end{array}$ & $11 / 130$ & - & $13 / 148$ & $2 / 14$ & $14 / 203$ & $20 / 338$ \\
\hline Other (Intl) & $7 / 46$ & - & $11 / 56$ & $8 / 41$ & $6 / 34$ & $4 / 25$ \\
\hline
\end{tabular}

Source: OAG database for scheduled flights

Note: Weekly data are the data of first week in July for each selected year. 
Table 10. NEA Low Cost Carrier Profile

\begin{tabular}{|c|c|c|c|c|c|}
\hline Country & Airlines (code) & $\begin{array}{l}\text { Fleet } \\
\text { size }\end{array}$ & $\begin{array}{c}\text { Service } \\
\text { Starting Date }\end{array}$ & Key share-holder and /or parent airline & Main Hub \\
\hline China & $\begin{array}{l}\text { Spring Airline (9C) } \\
\text { Lucky Air }(8 \mathrm{~L}) \\
\text { West Air }(\mathrm{PN}) \\
\text { Juneyao Airlines* }(\mathrm{HO})\end{array}$ & $\begin{array}{l}41 \\
26 \\
14 \\
34\end{array}$ & $\begin{array}{l}\text { 18-Jul-05 } \\
\text { Jul-04 } \\
\text { 14-Jul-10 } \\
\text { Jun-05 } \\
\end{array}$ & $\begin{array}{l}\text { Shanghai Spring International Travel Service } \\
\text { Hainan Airlines Group (HNA) } \\
\text { Hainan Airlines Group (HNA) } \\
\text { Juneyao Group }\end{array}$ & $\begin{array}{l}\text { Shanghai Hongqiao Airport } \\
\text { Kunming Airport } \\
\text { Chongqing Airport } \\
\text { Shanghai Hongqiao Airport }\end{array}$ \\
\hline Japan & $\begin{array}{l}\text { Air Do } \\
\text { Jetstar Japan (GK) } \\
\text { Peach (MM) } \\
\text { Skymark Airlines (BC) } \\
\text { Solaseed Air (6J) } \\
\text { StarFlyer (7G) } \\
\text { Vanilla Air (JW) } \\
\end{array}$ & $\begin{array}{c}13 \\
18 \\
13 \\
32 \\
13 \\
10 \\
6\end{array}$ & $\begin{array}{l}\text { Oct-12 } \\
\text { 3-Jul-12 } \\
\text { Mar-12 } \\
\text { 19-Sep-98 } \\
\text { Jul-11 } \\
\text { 16-Mar-06 } \\
\text { 20-Dec-13 }\end{array}$ & $\begin{array}{l}\text { ANA, DBJ(Development Bank of Japan) } \\
\text { Qantas, Japan Airlines } \\
\text { ANA,First Eastern Investment Group and INCJ } \\
\text { Shinichi Nishikubo } \\
\text { Miyakoh Holding } \\
\text { Star Flyer Inc. } \\
\text { ANA }\end{array}$ & $\begin{array}{l}\text { Tokyo Haneda Airport } \\
\text { Tokyo Narita Airport } \\
\text { Osaka Kansai Airport } \\
\text { Tokyo Haneda Airport } \\
\text { Tokyo Haneda Airport } \\
\text { Tokyo Haneda Airport } \\
\text { Tokyo Narita Airport } \\
\end{array}$ \\
\hline Korea & $\begin{array}{l}\text { Air Busan (BX) } \\
\text { Eastar Jet (ZE) } \\
\text { Jeju Air (7C) } \\
\text { Jin Air (LJ) } \\
\text { t'way (TW) }\end{array}$ & $\begin{array}{c}12 \\
8 \\
15 \\
11 \\
7\end{array}$ & $\begin{array}{c}\text { Oct-08 } \\
\text { 7-Jan-09 } \\
\text { 2-Jun-06 } \\
\text { Jul-08 } \\
\text { Sep-10 }\end{array}$ & $\begin{array}{l}\text { Asiana Airlines } \\
\text { Privately owned, not listed } \\
\text { Aekyung Group } \\
\text { Korean Air } \\
\text { KDIC, YeaRimDang Publishing }\end{array}$ & $\begin{array}{l}\text { Busan Gimhae Airport } \\
\text { Jeju Airport } \\
\text { Jeju Airport } \\
\text { Jeju Airport } \\
\text { Seoul Gimpo Airport }\end{array}$ \\
\hline
\end{tabular}

Note: Fleet statistics as of June 2014. Service starting date refers to the date when the airline began to offer services under the current name.

*Juneyao Airlines provides similar services to those offered by network carriers and may not be a typical LCC. It is however been included in several industry LCC reports, and so included in our analysis.

Source: Company's official website and annual reports. 
Table 11. NEA LCC Service Overview as of July 2014

\begin{tabular}{|c|c|c|c|c|c|}
\hline Airline & Country & $\begin{array}{c}\text { Number of } \\
\text { domestic } \\
\text { destination } \\
\text { s }\end{array}$ & $\begin{array}{c}\text { Domestic } \\
\text { Weekly } \\
\text { frequency }\end{array}$ & $\begin{array}{c}\text { Number of } \\
\text { internationa } \\
\text { I destination }\end{array}$ & $\begin{array}{c}\text { Internationa } \\
\text { I Weekly } \\
\text { frequency }\end{array}$ \\
\hline Lucky Air & China & 44 & 1112 & 2 & 2 \\
\hline Ruili Airlines & China & 7 & 98 & - & - \\
\hline Spring Airlines & China & 38 & 1162 & 24 & 184 \\
\hline West Air & China & 35 & 576 & - & - \\
\hline HK Express & Hong & - & - & 17 & 164 \\
\hline Kong & - & 517 & - & - \\
\hline Air Do & Japan & 14 & & & 56 \\
\hline Lapan Co & Japan & 3 & 126 & 4 & - \\
\hline Jetstar Japan & Japan & 10 & 586 & - & 140 \\
\hline Peach & Japan & 10 & 346 & 9 & - \\
\hline Skymark Airlines & Japan & 14 & 1144 & - & - \\
\hline StarFlyer & Japan & 5 & 420 & - & 56 \\
\hline Vanilla Air & Japan & 3 & 126 & 4 & 162 \\
\hline Air Busan & Korea & 3 & 432 & 20 & 90 \\
\hline Eastar Jet & Korea & - & - & 15 & 152 \\
\hline Jeju Air & Korea & 5 & 400 & 19 & 56 \\
\hline Jin Air & Korea & 2 & 170 & 36 & \\
\hline T'way & Korea & 3 & 250 & 10 & 240 \\
\hline Source Conpiled & OAG & 3 & & \\
\hline
\end{tabular}

Source: Compiled with OAG airline schedule data for the first week of July 2014.

Table 12. LCC Entry to NEA Countries

(As of the $1^{\text {st }}$ Week of July 2014)

\begin{tabular}{|c|c|c|c|c|c|c|}
\hline \multicolumn{7}{|c|}{ Foreign LCC Entry to China (1st Week of July, 2014) } \\
\hline Chinese airports & $\begin{array}{c}\text { Number of } \\
\text { Foreign } \\
\text { LCCs } \\
\end{array}$ & $\begin{array}{l}\text { Number of } \\
\text { Japanese } \\
\text { LCCs }\end{array}$ & $\begin{array}{c}\text { Number of } \\
\text { Korean } \\
\text { LCCs } \\
\end{array}$ & $\begin{array}{c}\text { Frequency of } \\
\text { Foreign } \\
\text { LCCs } \\
\end{array}$ & $\begin{array}{c}\text { Frequency } \\
\text { of Japanese } \\
\text { LCCs }\end{array}$ & $\begin{array}{c}\text { Frequency of } \\
\text { Korean } \\
\text { LCCs } \\
\end{array}$ \\
\hline Guangzhou & 4 & 0 & 0 & 54 & 0 & 0 \\
\hline Hangzhou & 5 & 0 & 1 & 42 & 0 & 2 \\
\hline Shenzhen & 3 & 0 & 0 & 33 & 0 & 0 \\
\hline Shanghai Pudong & 4 & 0 & 1 & 31 & 0 & 7 \\
\hline Qingdao & 4 & 0 & 2 & 20 & 0 & 14 \\
\hline Xi'an & 5 & 0 & 2 & 20 & 0 & 6 \\
\hline Wuhan & 2 & 0 & 1 & 15 & 0 & 1 \\
\hline Chongqing & 1 & 0 & 0 & 14 & 0 & 0 \\
\hline Kunming & 2 & 0 & 0 & 14 & 0 & 0 \\
\hline Beijing & 3 & 0 & 0 & 12 & 0 & 0 \\
\hline Nanjing & 2 & 0 & 0 & 11 & 0 & 0 \\
\hline Chengdu & 2 & 0 & 1 & 9 & 0 & 2 \\
\hline Jinan & 2 & 0 & 2 & 9 & 0 & 9 \\
\hline
\end{tabular}




\begin{tabular}{|c|c|c|c|c|c|c|}
\hline Haikou & 2 & 0 & 0 & 8 & 0 & 0 \\
\hline Ningbo & 2 & 0 & 0 & 8 & 0 & 0 \\
\hline Changsha & 1 & 0 & 0 & 7 & 0 & 0 \\
\hline Nanning & 1 & 0 & 0 & 7 & 0 & 0 \\
\hline Shenyang & 2 & 0 & 1 & 5 & 0 & 3 \\
\hline Tianjin & 2 & 0 & 1 & 5 & 0 & 2 \\
\hline Guilin & 1 & 0 & 0 & 4 & 0 & 0 \\
\hline Shantou & 1 & 0 & 0 & 4 & 0 & 0 \\
\hline Xiamen & 2 & 0 & 1 & 4 & 0 & 2 \\
\hline Yantai & 1 & 0 & 1 & 4 & 0 & 4 \\
\hline Quanzhou & 1 & 0 & 0 & 3 & 0 & 0 \\
\hline Changchun & 1 & 0 & 1 & 2 & 0 & 2 \\
\hline Hohhot & 1 & 0 & 1 & 2 & 0 & 2 \\
\hline Lijiang & 1 & 0 & 0 & 2 & 0 & 0 \\
\hline Taiyuan & 1 & 0 & 1 & 2 & 0 & 2 \\
\hline Yinchuan & 1 & 0 & 1 & 2 & 0 & 2 \\
\hline Dalian & 1 & 0 & 1 & 1 & 0 & 1 \\
\hline Harbin & 1 & 0 & 1 & 1 & 0 & 1 \\
\hline Hefei & 1 & 0 & 1 & 1 & 0 & 1 \\
\hline Nanchang & 1 & 0 & 1 & 1 & 0 & 1 \\
\hline Shijiazhuang & 1 & 0 & 1 & 1 & 0 & 1 \\
\hline Yanji & 1 & 0 & 1 & 1 & 0 & 1 \\
\hline Zhengzhou & 1 & 0 & 1 & 1 & 0 & 1 \\
\hline \multicolumn{7}{|c|}{ Foreign LCC Entry to Japan (1st Week of July, 2014) } \\
\hline Japanese Airports & $\begin{array}{c}\text { Number of } \\
\text { Foreign } \\
\text { LCCs }\end{array}$ & $\begin{array}{c}\text { Number of } \\
\text { Chinese } \\
\text { LCCs }\end{array}$ & $\begin{array}{c}\text { Number of } \\
\text { Korean } \\
\text { LCCs }\end{array}$ & $\begin{array}{c}\text { Frequency of } \\
\text { Foreign } \\
\text { LCCs }\end{array}$ & $\begin{array}{c}\text { Frequency } \\
\text { of Chinese } \\
\text { LCCs }\end{array}$ & $\begin{array}{c}\text { Frequency of } \\
\text { Korean } \\
\text { LCCs } \\
\end{array}$ \\
\hline Osaka Kansai International & 8 & 0 & 3 & 78 & 0 & 35 \\
\hline Tokyo Narita Intl & 6 & 0 & 3 & 58 & 0 & 28 \\
\hline Fukuoka & 5 & 0 & 3 & 42 & 0 & 28 \\
\hline Nagoya Chubu Centrair & 3 & 0 & 1 & 22 & 0 & 14 \\
\hline Tokyo Intl (Haneda) & 2 & 0 & 0 & 14 & 0 & 0 \\
\hline Sapporo New Chitose Apt & 2 & 0 & 2 & 11 & 0 & 11 \\
\hline Okinawa Naha Apt & 1 & 0 & 1 & 7 & 0 & 7 \\
\hline Hiroshima & 1 & 1 & 0 & 6 & 6 & 0 \\
\hline Ibaraki & 1 & 1 & 0 & 6 & 6 & 0 \\
\hline Saga & 2 & 1 & 1 & 6 & 3 & 3 \\
\hline Nagasaki & 1 & 0 & 1 & 3 & 0 & 3 \\
\hline Takamatsu & 1 & 1 & 0 & 3 & 3 & 0 \\
\hline \multicolumn{7}{|c|}{ Foreign LCC Entry to Korea (1st Week of July, 2014) } \\
\hline Korean Airports & $\begin{array}{c}\text { Number of } \\
\text { Foreign } \\
\text { LCCs } \\
\end{array}$ & $\begin{array}{c}\text { Number of } \\
\text { Chinese } \\
\text { LCCs }\end{array}$ & $\begin{array}{c}\text { Number of } \\
\text { Japanese } \\
\text { LCCs }\end{array}$ & $\begin{array}{c}\text { Frequency of } \\
\text { Foreign } \\
\text { LCCs } \\
\end{array}$ & $\begin{array}{c}\text { Frequency } \\
\text { of Chinese } \\
\text { LCCs }\end{array}$ & $\begin{array}{c}\text { Frequency of } \\
\text { Japanese } \\
\text { LCCs }\end{array}$ \\
\hline Busan & 4 & 0 & 1 & 21 & 0 & 7 \\
\hline Jeju International & 1 & 1 & 0 & 7 & 7 & 0 \\
\hline Seoul Incheon & 8 & 0 & 2 & 126 & 0 & 35 \\
\hline
\end{tabular}


Note: Summary statistics for China do not include LCCs in Hong Kong and Taiwan due to the special arrangements between these two regions with mainland China. 